\title{
Divergent Discourses, Children and Forced Migration
}

\author{
Giorgia Doná and Angela Veale
}

\begin{abstract}
Experiences of refugee, internally displaced and migrant children in different contexts (such as post-conflict and resettlement) are often considered separately, yet closer analysis points to the existence of commonalities across transnational locations and a need to articulate the ways in which global systems, state policies and migration processes impact on the lives of these children. Current discourses, policies and practices towards forced migrant children show that there are divergent and at times conflicting constructions of childhood and migration, and implicitly reveal the positions that these children occupy in relation to the nation-state system. In this article we focus on the existence of common divergent discourses that emerge from contexts in the global North and South, including Rwanda, Uganda, Ireland and the United Kingdom, where we have carried out research with children forced to move. Our overall aim is to repoliticise the position of child and youth forced migration through an analysis of three sets of divergent or ambivalent discourses: a) forced-migrant children as product of and threat to the nation-state; b) 'visible' and 'invisible' children; and c) the 'psychological' and the 'political' child.
\end{abstract}

Keywords:

Refugee; Children; Political; Discourse; Rwanda; Uganda

Introduction

Forced displacement is both a threat to, and a product of, the international system of nation-states. It therefore exposes fundamental inconsistencies in the ideology that underlies the nation-state system (Turton 2002: 20).

Turton's analysis of the relationship between forced migration and the nation-state system positions forced migrants at the intersection of displacement, migration, national belonging and citizenship. Forced migrants are obliged to flee because they do not fit within nation-state projects but they can only move to another nationstate, and not outside the international system of nation-states. Turton refers to forced migrants in general. In the last few years, there have been increased concerns about children displaced by conflict and forced to flee*either internally or across borders*to become asylum-seekers and refugees.

Most researchers who analyse childhood and forced migration do so in the context of one specific country (i.e. Christie 2003; Christie and Sidhu 2006; Giner 2007; Lane and Tribe 2006; Spicer 2008). While there is a growing body of literature that discusses the challenges faced by forced-migrant children in the context of Europe and the UK, it is rare for such work to interact with the experiences from the global South, where children are displaced in large numbers (Boyden and Hart 2007).

A useful approach is to explore examples that point to transnational commonalities in the ways in which forced-migrant children are represented. Furthermore, forced-migrant children's experiences are generally represented through the prism of psychology and mental health (Ahearn et al. 1999; Dona' 2006; Hodes 2002; Loughry and Eyber 2003; Summerfield 2000; Thomas and Lau 2002). A key motivational concern in this literature is a child protection agenda and the development of effective psychosocial and mental-health interventions. However an intended or unintended outcome of positioning forced-migrant children as beneficiaries of humanitarian assistance and needs-based social-care programmes is that it places their experiences outside political discourse. This coincides with reported real-life experiences of forced-migrant children*such as those in the UK* who are pressured into de-politicising their experiences, once they become applicants in the asylum process, by appearing sufficiently 
'victim-like' and not too 'political' and by downplaying their own political engagement (Crawley 2007; Crawley, this issue).

While recognising the important contribution which the literature from a child protection perspective has made to our understanding of the impact of forced migration on children's lives, our aim here is to re-politicise child forced migration. We use the term 'forced-migrant' child to refer to children who have fled violence in general, independent of whether they are inside the country (internally displaced), have crossed an international border (refugees or asylumseekers), or have returned to the country of origin (returnees). We take Boyden and Hart's (2007) call for a greater interaction across different bodies of literature and attempt to expand it through a comparative analysis of migration and childhood that draws attention to the position that forced-migrant children occupy within the system of nation-states. Turton (2002: 22) writes that the nation-state concept is a fusion of two assumed entities: that of a nation as a 'homogenous cultural community' with common interests, and that of a state as a geopolitical entity, with its bureaucratic and administrative apparatus and political structures that govern the territory, laws about who may enter and leave that territory and conditions of rights to remain. In reality, he points out that many nation-states do not demonstrate this ideal and are more accurately conceptualised as 'multi-nation states' as a result of the co-existence of more than one cultural or ethnic group that belong within the geopolitical state entity. Yet the nation-state concept is predicated on an acceptance of the assumption of this ideal: that the state as territory and political apparatus overlaps with the nation as a community of belonging, and equal citizenship for its members. He points out that the nation-state system has been immensely successful at one level as it has enabled the movement of the citizens of one nation-state to another to be politically administered in an efficient and predictable manner.

Forced migration, however, exposes inconsistencies in the way in which the international system of nation-states functions. For example, many recent conflicts have occurred in situations in which national or ethnic identity has become mobilised as a marker of 'belonging' to the nationstate and those who do not 'fit' or become 'other' or 'not like us' may be stripped of their rights as equal citizens. The victims of conflict become constructed as a risk or threat to the 'ideal match' between the nation and the state, and may experience displacement or even expulsion (as in Rwanda, Eritrea or Bosnia for example). In such cases, forced migrants can only flee to another nation-state*and not outside the system of nation-states*therefore presenting a challenge for the 'ideal match' in other nation-states. As such, forced migration is frequently the product of nationstate building or maintenance, while simultaneously posing a threat to the nation-state and, through their cross-border movement, to the nation-state system. Internally displaced individuals, too, highlight an inconsistency in the nation-state system whereby forcibly uprooted minorities are positioned as marginalised in terms of 'equal' claims to citizenship.

Children tend to be subsumed as a social category in considerations of the relationship between the nation-state system, citizenship and belonging. In this article we explore three sets of divergent or ambivalent discourses: a) forced-migrant children as a product of and as a threat to the nation-state system b) visible and invisible children and c) the psychological and the political child. We argue that children who are displaced by violence, live in post-conflict contexts or seek asylum, share commonalities in their position with respect to individual nation-states as well as in relation to the global system of which these nation-states are part. These divergent discourses expose fundamental gaps, tensions and inconsistencies in the ideology of the nation-state system per se.

\section{Re-Politicising Child Forced Migration: An Exploration of Divergent Discourses}

Discourse is language as a system of representation, a meaning-making activity that constructs the topic and functions as social action. 'To enter into the study of discourse, therefore, is to enter into debates about the foundations on which knowledge is built, subjectivity is constructed and society is managed' (Wetherall et al. 2001: 5). We analyse a combination of such discourses produced within legal and political environments to show that there are similarities in forcedmigrant children's position within the nation-state system, and to argue for their re-politicisation. 
Our awareness of the need to re-politicise the experiences of displaced and forced migrant children stems from Rwanda, where we realised*for many years after the 1994 genocide*how apparently-apolitical psychological interventions for children functioned in a political space (Veale and Dona' 2002). We noted how many policies and programmes with displaced and war-affected children were couched in politically neutral child-protection language while simultaneously, in practice, children were identified as 'vulnerable' and in need of protection with reference to postgenocide discourses that assumed the existence of differential claims to 'equal citizenship'.

We observed that, in post-genocide Rwanda*a country signatory to the 1989 Convention on the Rights of the Child*child survivors of the genocide received support while the children of those accused of involvement in the genocide received none, even though Rwandan children themselves identified children of families accused of acts of genocide as even more vulnerable than genocide orphans, as they were isolated, many in child-headed families, and had the responsibility of bringing food to the parent in prison (Veale et al. 2001). A post-genocide nationstate discourse of unity and reconciliation*'We are all Rwandans'*according to which each child was to be viewed as a child of the nation-state, coexisted with politics of 'genocide victimhood' that positioned some categories of children as less-deserving 'others' in the national project of nation-state redefinition. In our subsequent fieldwork in the different contexts where we worked*Uganda, Ireland and the UK* we became aware of the existence of divergent discourses about childhood and nation-state maintenance that presented similar tensions. While singlecountry studies might allow fully contextualised and detailed accounts of the experiences of forced-migrant children, they fail to highlight the connections and parallels across different states where these children find themselves. We adopt a multi-country approach in order to shift the focus from a predominant analysis of childhood and asylum to the geo-politics of childhood and forced migration. We selected these countries based on our experience of working there. These countries are also interesting because of their different geo-political positions in the North and the South, their migratory histories as sending and receiving countries, and the different phases they represent in the formation and maintenance of their nation-state ideologies.

The 1994 genocide created a rupture in Rwanda's national history, still in the process of redefinition and reconstruction. The formation in July 1994 of the new Government of National Unity under the influence of key figures within the Rwandan refugees' diasporic community who returned after 1994 is an example of a country in the process of recreating its national identity in which the genocide and its legacy play a central role, and where ethnicities have been legally banned under the national slogan 'We are all Rwandans'. Uganda's post-colonial history of nationbuilding is more consolidated than that of Rwanda, but continuous political tensions between the central Government and the north of the country, with its recent history of conflict by the Lord's Resistance Army, show how different agendas of belonging within the nation-state are still contested, and how forced mobility is played out within these struggles of peace negotiations and reconstruction. Rwanda and Uganda are positioned within global migration in the role of sending countries. The outmigration flux reaches not only neighbouring regions but also the borders of Western countries in North America, Australia and Europe. Here, Ireland and the United Kingdom, among others, occupy the position of receiving countries of forcedmigrants' movements.

Ireland's history has been traditionally characterised by out-migration, and it was only in the last two decades of economic boom that the Irish state was confronted with the new phenomenon of the in-migration of East Europeans and forced migrants from the global South. Ireland's recent history of migration challenges what it means to belong and it struggles to re-imagine itself as a host country to people arriving around from the world. The UK has a longer history of engagement with issues of migration and multiculturalism. Its past history of Empire and Commonwealth memberships means that there have been tensions between what it means to be British and to belong for some time.

Forced Migrant Children: Product and Threat 
Turton (2002) writes that forced migration is both the product of and a threat to the system of nation-states. This is due to the imperfect overlap between the 'nation', intended as a community of belonging, and the 'state' as its legal, political and administrative apparatus. Forced migrants are often a product of the nation-state system because the formation or reformation of nationstates may be accompanied by the expulsion of those deemed not to fit within the nation-state project. Forced migrants are also a threat to nation-states because, when expelled by one nation-state, they can only ask for asylum in another and, in so doing, threaten the existing match between nation and state, as do national minorities.

Boyden and Hart (2007) write that asylum-seeker and refugee children tend to be seen as either victims or threatening individuals. As victims they are perceived to be innocent and in need of help while, as threat, they are to be controlled or re-educated. Thus, adapting Turton's (2002) statement, forced-migrant children are both the 'product' of and a 'threat' to the nation-state system. As product, they are victims in need of help while, as threat, they are criminalised as undeserving of those rights belonging to citizens.

The Rwandan case shows the complex dynamics between discourses of childhood as product and those as threat in the context of a nation-state in crisis. For the Parme-Hutu genocidal regime in pre-genocide Rwanda, children of Tutsi descent were considered a threat to the nationstate project that was based on a racist Hutu ideology of 'ethnic purity'. They were called 'cockroaches' and 'small rats', and targeted for extermination. Those few Tutsi children who managed to survive the genocide were called 'rescapees' and, as such, became constructed as the product of the racist Hutu ideology and its victims. In post-genocide Rwanda, rescapee children became central to the self-definition of the new Tutsi-dominated state as a victimised nation and other categories of children came to be perceived as a threat to the formation of this new nation-state. This included children accused of involvement in the genocide, the children of genocidaires and street and forced-migrant children living in Eastern Congo. Our work on streetlife involvement in Rwanda showed that most youth living on the street were doing so because of political violence (Veale and Dona' 2003). These Rwandan youth did not easily fit within the postgenocide nation-state project; they were perceived as a 'threat' to order and unity, and were regularly picked up from the streets and sent to be re-educated in secluded areas.

Children who have been formerly abducted or conscripted into the armed forces constitute an additional example of the tension between discourses of forcibly moved children as a product of and as a threat to the nation-state system. In Uganda, former child-soldier abductees reported that they were welcomed back, as people saw that they were victims who had been taken against their will; however, if they got angry or aggressive for any reason, they experienced a shift from being identified as a friend or peer to identification as a 'rebel' (Veale and Stavrou 2007). In international discourse, and increasingly within international law, former child soldiers are considered primarily as victims of conflict ( $\mathrm{Co}^{\wedge}$ te' 2005: 4). Yet there is significant dissonance between this discourse of victimhood evident at an international level, and discourses within national-level systems in the global North when former child soldiers apply for refugee status and are perceived as a threat. There are concerns that former child soldiers, including those from northern Uganda, have been excluded from refugee status in the UK by the application of Article 1Fa of the Geneva Convention Relating to the Status of Refugees, by which 'states are obliged to refuse refugee status to any persons "with respect to whom there are serious reasons for considering that ... he has committed a war crime, or a crime against humanity"' (Happold 2002: 1133).

Adolescent forced migrants are also caught up in such tension. As a product of political violence, they are primarily treated as children and victims and, if unaccompanied, are offered protection under the UK 1989 Children's Act rather than the 2004 Asylum and Immigration Act. However, in age disputes, in Ireland and in the United Kingdom, youth aged $16 ! 18$ years who do not fit the dominant view of 'children' may find themselves in a disadvantageous position when claiming asylum (Crawley 2007). When their ages are disputed, in age assessment interviews, the burden of proof is on young people to prove that they are under the age of 18. In the UK, in some cases, children whose ages are disputed are detained in Young Offenders' Institutes and some in adult 
prisons on arrival. Increasing numbers of asylumseeking children are placed in detention. In the UK, in 2004, around 2,000 children were being held in detention centres for periods that ranged between 7 and 268 days (Crawley and Lester 2005: viii). In September 2008, lawyers challenged the legality of detention for children when they took the case of an eight-year-old boy*detained in an immigration removal centre since July*to the High Court (BBC Radio 4, 2008). Detention criminalises children*whether unaccompanied or as members of the family unit*as the 'threatening other' (or the new generation of hordes of threatening 'others') who is to be confined or re-educated. The deportation of children and families whose asylum claim has been rejected is also predicated on the

view that these children are the 'other' who 'threaten' national belonging, and are to be expelled.

In recent years Ireland, for instance, has introduced a number of containment measures to stem an in-flow of asylum-seekers that is perceived to be threatening 'Irish national identity'. One such measure is the Irish Nationality and Citizenship Bill (2004), which effectively removed the entitlement to citizenship in respect of a person born in Ireland to non-national parents. This change was approved by 80 per cent of the population in a citizenship referendum. A nonnational child will only be given citizenship if one of the parents has been lawfully resident in the country for three of the four years before the birth. This changed the nature of 'belonging' from citizenship that was defined by territory*jus soli*whereby citizenship was conferred on all children born on the territory of the nation, to jus sanguinis, or the law of blood, under which citizenship is inherited. Two babies born on the same day in the same hospital in Cork or Dublin may now differ in one very significant respect*one may be accorded the full rights of citizenship, while the other is denied this basic status of belonging.

In 2005, the Irish government established the Irish-Born Child Residency Scheme, under which a non-national parent who had a child born in Ireland before 1 January 2005 could apply for residency. Applications were open for a three-month period. In total, 16,693 individuals were granted residency under this scheme for an initial period of two years. However, a core part of this bill was that parents who were allowed to remain on the basis of having an Irish-born child had to sign a declaration affirming that they have no entitlement to family reunification*including reunification in Ireland*with spouses and dependent children. This has created significant distress and has remained unchanged under the Immigrant, Protection and Residency Bill (2008). In practice, this has had the effect of separating Irish-citizen children from a second parent or siblings where such family members exist in another country. Furthermore, under this scheme, humanitarian leave to remain is granted just for the parent(s) and the Irish-born child. Any other children have to apply in their own right. This has resulted in unequal legal status for different children within the same family. These policies, which deny Irish-born children and their nonnational siblings some of their rights as children, are arguably a response to the threat that forced-migrant children pose to the 'ideal match' of the Irish nation-state and its politically structured categories of belonging.

Our analysis has shown the existence of divergent discourses of children as both a product of and a threat to nation-state formation and maintenance. Orphans, separated children, unaccompanied minors, genocide survivors, or refugee children are visible mainly as a 'product' of the system of nation-states, and are treated as its victims. Adolescents, former child soldiers, or street youth are visible but repeatedly perceived as a 'threat' to national and international unity and belonging. As products of violence, children tend to be viewed as victims, apolitical, in need of protection and through the lenses of trauma. As a threat to cohesion and national unity in politically and ethnically divisive societies, they are deemed to be in need of re-education, detention or deportation. The product! threat dichotomy is neither categorical, nor fixed, nor permanent but, rather, contextual and relational, with children moving or being moved across its boundaries, and in constant tension. The existence of similar processes of inclusion and exclusion across different countries in the global South and North that are couched in neutral terms of vulnerability and protection underlie ambivalent discourses that are politically driven and as such need to be explicitly re-politicised.

Visible and Invisible Children 
Another paradox of the system of nation-states is evident in those divergent discourses that position some children as highly visible*mainly through the lens of apolitical needs*and others as invisible, and that elucidate tensions in claims to nationality and belonging. Child-rights discourses encapsulated in international instruments such as the Convention on the Rights of the Child oblige state parties to respect children's rights without discrimination, irrespective of the child's or his or her parents' nationality, ethnicity or other such status and include the right from birth to a nationality. The predicament of stateless children exposes one of the fundamental inconsistencies in the ideology of the nation-state system as a whole. At the core of the system of nation-states is the right to citizenship and belonging. Every person belonging to a state or asking for asylum in another state is negotiating access to citizenship within the global system, relinquishing it in one state and applying for it in another. However, there are children who do not belong to any nation-state, and who do not have claims to citizenship anywhere*they are the 'stateless children'. Among them are the Bihari children in South Asia, the Bidoon in Kuwait, the Kurds in Syria and millions of Palestinians in the Middle East and North Africa (Frelick and Lynch 2005; Sen 2000). These children are legally non-existent, invisible not only in relation to individual nation-states but also to the system as a whole. They are caught in the gaps in the existing nation-state system, and are outsiders not to its constituting elements*nation-states*but to the system per se.

Changes in migration patterns, asylum and migration frameworks, and the increase in the number of irregular and undocumented migrants, means that 'statelessness' as an existential condition is shared by many other categories of children (Boyden and Hart 2007). In our work with Rwandan separated children displaced during mass movements in 1994, children informally fostered by Congolese families became invisible (Dona' 2001). Not registered as Rwandans living abroad, the Convention rights of these children to an identity are challenged and their conditions unreported. In contrast to the 'rescapee' children mentioned earlier, who were central to the Rwandan post-genocide nation-building project, these separated children are invisible in the system of nation-states; they do not legally belong to either the Rwandan or the Congolese nation-state, and their entitlements for the future are unclear.

Separated children who travel irregularly, those who are trafficked or are the offspring of undocumented migrants or asylum-seekers whose claims have been rejected are examples of legal invisibility. The fate of those Ireland- and UK-born children of irregular migrants and failed asylum-seekers is unclear, and they are faced with potential statelessness. In Ireland, there are no figures on the numbers of dependents or children who may have arrived with, or followed workers from, the accession states of Eastern Europe since May 2004. There is no onus on families to register them with any state bodies until they are 16 years of age, when they must then be registered with the Garda National Immigration Bureau (GNIB). This invisibility of immigrant children also raises questions about how this may inadvertently be supporting conditions that give rise to trafficking and exploitation.

Many separated children are not entered in the Irish asylum process and thus are invisible in official asylum statistics. This may be because a social worker deems that the asylum process may be too traumatic for them or because of restrictive conventional definitions of 'refugee' to date, which would be inapplicable to children who may have experienced 'private' trauma, such as incest, rape and other physical abuse, or trafficking by a parent (Mooten 2006). These children and young people have no current legal status and no long-term protection rights, and may face deportation once they reach 18 years of age. Furthermore, of those separated children known to the authorities, more than 350 have gone missing from their care placements in recent years (Irish Refugee Council 2006). The Health Service Executive (HSE) has not made public any information about these children but there are documented cases of child trafficking which have never received the political or social attention merited by their potential seriousness.

In the UK, Bokhari (2008) exposes the challenges facing trafficked children, including the shortcomings and inconsistent standards of local authorities, the lack of specialist protection and the uncertainty of these children's immigration status, all of which result in the disappearance 
without trace of many children from localauthority care and in their mental-health issues going undetected and untreated.

It is not only those children who get caught in the gaps of the system who are invisible but also those who sit uncomfortably in between a rhetoric of national unity and belonging and a reality of national and international tension. The predicament, for instance, of those Rwandan children whose parents are charged with involvement in the genocide, of child soldiers asking for asylum in European countries, and of children born of rape, are a few examples of narratives of invisibility due to an uneasy fit with dominant divergent discourses.

Children also become invisible when they do not fit the language of needs as a child, such as young carers or those minors who claim refugee status on their own terms. Evidence from the UK suggests that separated children find it much more difficult than adults to gain asylum (Bhabha 2004). They have difficulty in obtaining adequate legal representation, their cases are more likely to be postponed and to drag over time, and they have fewer chances of being granted refugee status. The implicit assumption that refugees are adults means that threats facing children as political activists in their own right or as members of targeted families are often ignored or trivialised and that child-specific forms of persecution*such as child-selling or trafficking*are not considered to fall within the ambit of the five grounds for persecution: race, religion, nationality, membership of a particular social group and political opinion. Discourses of invisibility dominate and result in these children being 'treated differently rather than equally' (Bhabha 2004: 143).

In conclusion, complementary to discourses of visibility are those of invisibility that highlight additional gaps and inconsistencies in the system of nation-states for those children who are caught outside it, those who sit uncomfortably in between contradictory political discourses or those who do not fit dominant perceptions of childhood. The 'invisibility' of certain categories of children exposes inconsistencies in claims to nationality and belonging. Implicit assumptions about social categories of 'children' influence which children are more likely to receive support and, more importantly, which children and young people are rendered invisible and untargeted. Some children may be privileged or marginalised as a consequence of their goodness of fit with political or social concepts of 'children as citizens' in the nation-state system. Therefore, across different contexts in the global South and North there are similar ambivalent discourses of visibility and invisibility that, although framed in terms of neutral needs, expose political constraints.

\section{The Psychological and the Political Child}

In the introduction, we pointed to the widespread tendency amongst researchers to make sense of children's experiences of displacement and involuntary migration through the apolitical prism of psychological concepts such as trauma and mental health and psycho-social needs. In our attempt to re-politicise the position of forcedmigrant children, we now examine the existence of divergent discourses that construe the psychological and the political forced-migrant child. Specifically, we want to raise awareness of the fact that psychological discourses about forcibly uprooted children which appear apolitical on the surface, in reality function in political spheres in ways that can support the construction and maintenance of nation-state projects.

Conversely, psychological discourse is sometimes used on behalf of or by forcedmigrant children to protect their needs and rights 'as children', and as a form of resistance in political spaces where they fall outside systems of national rights and entitlement (such as the asylum system) or are denied rights conferred by belonging and citizenship (the internally displaced). We see this phenomenon as a tendency to 'psychologise the political' and 'politicise the psychological'. In our work in Rwanda, we observed the tendency to frame children's experiences of genocide and war within apolitical discourses of trauma, vulnerability and psychosocial needs (Veale and Dona' 2002) and, in Rwanda to date, these discourses prevail (Thomson 2007). However, as time went by, we noticed that trauma and psychosocial interventions, framed within apparently apolitical care-models of assistance, in reality contributed to legitimise a political victim/perpetrator 
dichotomy that rendered invisible those children who did not fit dominant accounts of victimhood, and minimised the existence of fragmented relations under a post-genocide national discourse that focused on unity and reconciliation.

The 'psychologising' of the genocide and its aftermath has meant that the needs and rights of children were primarily addressed on the basis of their perceived 'traumatic' and psychosocial vulnerability. Certain categories of children (such as survivors of the genocide and orphans) fitted better than other groups of children (such as those displaced immediately after and in the years following the genocide) within the trauma discourse and were offered more financial aid and support, independent of the fact that all children had been living through political violence, and that some of them became 'vulnerable' in post-genocide Rwanda because of a lack of family support or due to multiple displacements. In this context, the construction of the traumatised child came to be associated with genocide child survivors rather than with children of war. It contributed to validating an overt official 'psychological' narrative of events that distinguished child genocide victims from children of perpetrators and bystanders in terms of the degree of trauma to which they were subjected or which they inflicted, and that legitimised differential interventions. The apparent neutral and universal concept of trauma that contributed to the definition of the categories of children in need was in reality used for a Tutsidominated government's political purposes to sanction an official narrative of social suffering reliant on the centrality of the genocide and of 'national unity', and which masked the existence of dissenting voices and different experiences of war and displacements. When viewed through the lens of the 'psychological' child, forcedmigrant children are constructed as having universal yet somewhat apolitical identities that are consonant with constructions of the child as victim in need.

In northern Uganda, psychological interventions such as psychosocial rehabilitation and reintegration programmes have played a key role in depoliticising former child-abductees' identities from their previous role as fighters to return them to lesspowerful and arguably moredependent roles within civilian society. Community members described returned children and young people who had been through psychosocial reintegration programmes as 'less rude' and as 'having more respect for people and elders' (Veale and Stavrou 2007). In northern Uganda this programming has tended to depoliticise the position of children and call for a focus on child rights and welfare. However the centrality of abducted children's experiences to the conflict raises an uncomfortable question*how have stories of children's traumatic experiences functioned in political spaces? The roots of this conflict lie in political disenfranchisement and systematic, long-term, regional underdevelopment. At the height of the conflict, the response through the creation of 'protected settlements' resulted in 90 per cent of the Acholi population living as internally displaced. The plight of child abductees became the local and international symbol of the horrors of this conflict. To a large extent, economic and political discourse was put to one side as human rights and child protection voices dominated. The brutalisation of children by the Lord's Resistance Army (LRA) positioned the conflict (and the region) as beyond the bounds of rationality and this was further supported by reference to the LRA's spiritual beliefs, and its branding as a 'terrorist' organisation. Arguably the focus on abducted children as a symbol of this conflict served to deflect international attention from the underlying political and economic roots of the conflict, the factors maintaining the conflict*such as life within the protected settlements ${ }^{\star}$ and issues of political, regional and social development. Acholi society now comprises an economically underdeveloped and politically alienated grouping of predominantly internally displaced people*all in a country that, during the 1990 s, experienced one of the highest rates of per capita income growth in the world, with economic growth remaining consistently steady since then. A focus on child victimhood and need has 'psychologised' the political. It also failed to support, or advocate for any claims by, the 90 per cent of internally displaced children to 'equal citizenship' and belonging within the nation-state of Uganda.

In the UK, the functioning of psychological discourses in political spaces can be explored through a focus on social workers and counsellors who work inside detention centres to support forcedmigrant children's wellbeing (ILPA 2004; Refugee Council 2003). Psychological interventions in these centres indirectly validate the existence of these centres for dealing with the management of migrant children, and thus position asylum-seeking children and families in detention within 
socio-political frameworks of security and criminalisation rather than of protection. Ambivalent psychological and political discourses of the position of children in relation to the project of national belonging mean that political concerns become displaced and overtly reduced to psychological ones while covertly fulfilling political purposes. If apparently apolitical psychological interventions fulfil political functions in the development and maintenance of nation-states, with their dichotomised assumptions of inclusion and exclusion, and constructions of the citizen and the alien, and the genuine and the bogus claimant, the reverse phenomenon also takes place. There the psychological is overtly politicised, while its political utilisation has psychological outcomes. In the UK, the mandatory use of dispersal for asylum-seekers without support has placed non-governmental organisations, advocacy groups and legal-aid agencies in the controversial and at times ethically difficult predicament of taking the decision to label their clients as suffering from post-traumatic stress disorder or mental illness and to resort to the label 'traumatised' to help their clients to postpone or avoid compulsory dispersal on the grounds that specialised mental-health facilities are not available across the country. In Ireland, mental-health professionals working with unaccompanied minors have utilised psychological assessments to make a case against the transfer of asylum-seeker minors who 'age-out' of the system of care for minors to the adult 'direct provision' system*a discriminatory system of meeting the basic needs of asylum-seekers by providing accommodation and food in designated accommodation centres and a stipend of 19.10 euros per week. In this instance, the construction of the traumatised asylum-seeking child or family serves to resist one aspect of the asylum process. The psychological label is overtly used for political purposes by certain categories of social actor, but there is a risk that this use impacts negatively on the social wellbeing of the asylum-seeking child and family, who are then obliged to carry the stigmatising label. Rather than pathologising them, there is a need to re-politicise the psychological in order to accuse the asylum system as being detrimental to childrens's and families' rights to freedom of movement and wellbeing.

We thus observe a series of ambivalent or divergent discourses of the child as a political or psychological subject. These discourses highlight the tension between an apolitical view of childhood as part of a shared humanity with universal rights as 'children', and children as political entities in terms of their identity and the validity or otherwise of their claims to citizenship and belonging within a single nation-state and the nation-state system.

\section{Conclusion}

In this article we have offered a political analysis of the position of forced-migrant children in relation to the system of nation-states. Our contribution here is twofold: first, we have tried to move away from single-country studies and to offer an analysis of the geo-politics of child forced migration; secondly we have argued for the need to re-politicise child and youth migration against the ongoing tendency to de-politicise it within psychological models of welfare and mental health. Other writers have discussed the position of migrants and refugees in relation to nation-states, examined the relation of children to asylum policies and pointed to the increasing tension among existing models of welfare, migration management, child policies, and equality and discriminatory practices (Christie and Sidhu 2006; Giner 2007; Lane and Tribe 2006; Spicer 2008). Individualcountry analyses, as in the case of the UK, show that responses to changing patterns of migration and global realities are ad hoc and reactive (Giner 2007).

We have spelled out the specific discourses and positions of children vis-a'-vis the nation-state system, and shown that underneath fragmented and context-specific responses to forced migration lie transnational commonalities in the way in which divergent discourses of children and migration are construed. We have focused on the existence of common divergent discourses that emerge from contexts in the global North and South*in Rwanda, Uganda, Ireland and the United Kingdom*where we have studied children forced to move. Our overall aim was to repoliticise the position of forced-migrant children and young people by analysing three sets of divergent discourses which are manifested in current policies, laws and practices: children as a 'product of ' and as a threat; visible and invisible children; and the psychological and the political child. 
In Rwanda and Uganda, ambivalent discourses relating to children who have experienced forced movement sit uncomfortably within national projects of development and unity; in Europe these discourses are directed towards newcomer children who challenge ideas of belonging. Turton (2002) writes that the fundamental paradox that forced migration exposes is one of 'equal claim to citizenship'. These discourses show a tension between the construction of the child as 'child' (apolitical, in need, subjected to inclusive policies and welfare provisions) and of the child as 'migrant'. On the one hand, inclusive policies on children assert that individuals are 'children first and displaced/asylum-seekers second'. They operate by asserting the neutral and apolitical character of childhood. Within this view, children are the subjects of welfare and child-protection policies, of psychosocial interventions and support. On the other hand, migration policies operate in the political domain, and children are classified by their political status vis-a'vis the nationstate (as citizen/ non-citizen, different, inferior or with unequal claims to entitlements of citizenship).

Interventions for children deemed not to belong to or fit with the common interests of the nationstate project often seek to contain, re-educate or expel. When the politics of childhood and those of migration intersect, defensive and discriminatory nation-state approaches occur. There is a need to re-politicise uprooted children's positions as children and as global citizens within the nation-state system (rather than within individual nation-states). For children, the inconsistency is between the right to 'equal claims to citizenship' and to 'childhood' in politically situated contexts.

The divergent discourses that we have discussed give us an insight into how uprooted children expose gaps, limitations and inconsistencies in the dynamics of nation-state formation, development and maintenance, and in the system of nationstates. Nation-states find it difficult to reconcile the tension between the moral right to protection without discrimination in the name of 'childhood' on the one hand, and the 'politics' of child forced migration on the other. They struggle to resolve divergent views of childhood as 'apolitical' and therefore having a claim to fit within the global nation-state system without discrimination, and the fact that some children are explicitly (in law) or implicitly (in practice) viewed as fitting more 'naturally' than others within existing nation-states' ideas of belonging. In other words, nation-states struggle to bring together inclusive child-policy frameworks that view displaced, refugee, asylum-seeking and returnee children as children with equal rights to global citizenship, and exclusive national or asylum frameworks which view certain categories of children as the 'other'.

There are two general concluding comments to our analysis. The first is that ad hoc and unfocused responses will continue to exist because they reflect not fundamental inconsistencies of individual nation-states but a fundamental tension inherent in the system of nation-state formation and consolidation: the matching of ideals of nation and state. As long as the nationstate system remains as it is, the best that can be hoped for is compromise that supports the formation and consolidation of the coexistence of childhood with citizenship. In this respect, the 1989 Convention on the Rights of the Child, a 'universally agreed set of non-negotiable standards and obligations' (www.unicef.org/crc/), conveys a specific type of global narrative: children have rights. This positions children across the world into a specific relationship with the nation-state system, one in which they have rights as citizens and as children. However, there are discrepancies in this narrative, such as when children who are forced to migrate due to conflict discover that the basic principles enshrined in the Convention do not necessarily translate into practice for them. For example, the UK government reservation about Article 22 of the CRC on refugee children is an example of the tension between national and international narratives and expectations regarding the rights of children forced to flee. In this context, the $\mathrm{CRC}$ is an appropriate tool with which to overcome divergent perceptions, responses and narratives about children in relation to nation-states by incorporating two elements *citizenship and childhood ${ }^{*}$ which are at the core of current discrepancies and inconsistencies.

The second and alternative perspective is to put under scrutiny the permanent existence of the system of nation-states per se in its current incarnation. Christie (2003) does so when discussing social work practices with asylum-seeking children. The creation of social work as a profession is closely associated with the formation of the welfare state and nation-states. Work with asylum- 
seeking children challenges social-work practice as a by-product of the nation-state and, in order to overcome these challenges, there is a need for social work to move towards post-national frames of care. A similar position is advocated by those who support open borders (i.e. Cohen 2006) not only for capital and technology (which are already present) but also for the movement of people. The European Union, as one model of a regional open border, shows that the gaps and inconsistencies between the ideal matching of nation and state would be reduced and would disappear. It is unclear what this will entail in order to ensure that the rights of children as global citizens can be upheld.

\section{References}

Ahearn, F., Loughry, M. and Ager, A. (1999) 'The experience of refugee children', in Ager, A. (ed.)

Refugees: Perspectives on the Experience of Forced Migration. London: Cassell, 215!36. BBC Radio 4 (2008) 'Immigration: is it time to stop detaining children?', online at www.bbc.co.uk/radio4/womanshour/02/2008_36 fri.shtml, accessed 23 November 2008.

Bhabha, J. (2004) 'Seeking asylum alone: treatment of separated and trafficked children in need of refugee protection', International Migration, 42(1): $141 ! 8$.

Bokhari, F. (2008) 'Falling through the gaps: safeguarding children trafficked into the UK', Children and Society, 22(3): 201!11.

Boyden, J. and Hart, J. (2007) 'The statelessness of the world's children', Children and Society, 21(4): $237 ! 48$.

Christie, A. (2003) 'Unsettling the "social" in social work: responses to asylum seeking children in Ireland', Child and Family Social Work, 8(3): 223!31.

Christie, P. and Sidhu, R. (2006) 'Governmentality and "fearless speech": framing the education of asylum seeker and refugee children in Australia', Oxford Review of Education, 32(4): 449!65.

Cohen, S. (2006) Standing on the Shoulders of Fascism: From Immigration Control to the Strong State. Stoke on Trent: Trentham Books.

Co^te', L. (2005) Prosecuting Child Related Crimes at the Special Court for Sierra Leone: A Mid-Term Assessment. Expert Discussion on Transnational Justice and Children, 10!12 November. UNICEF, online at http://www.unicef-irc.org/research/pdf/TJC Annex 2007 FINAL.pdf, accessed 5 May 2011.

Crawley, H. (2007) When is a Child Not a Child? Asylum, Age Disputes and the Process of Age Assessment. London: ILPA, http://www.ilpa.org.uk/publications/ILPA\%20Age\%20Dispute\%20Report.pdf

Crawley, H. and Lester, T. (2005) No Place to be a Child: Children in UK Immigration Centres. London: Save the Children.

Dona' , G. (2001) The Rwandan Experience of Fostering Separated Children. Stockholm: Save the Children.

Dona' , G. (ed.) (2006) Special Issue on Child and Youth Migration: Changing Trends and Responses. International Journal of Migration, Health and Social Care, 2(2).

Frelick, B. and Lynch, M. (2005) 'Statelessness: a forgotten human rights crisis', Forced Migration Review, 1(24), available at http://www.fmreview.org/mags1.htm, accessed 6 June 2009.

Giner, C. (2007) 'The politics of childhood and asylum in the UK', Children and Society, 21(4):249!60.

Happold, M. (2002) 'Excluding children from refugee status: child soldiers and Article 1F of the Refugee Convention', American International University Law Review, 17(6): 1131!76.

Hodes, M. (2002) 'Three key issues for young refugees' mental health', Transcultural Psychiatry, 39(2): $196 ! 213$.

ILPA (2004) Working with Children and Young People Subject to Immigration Control: Guidelines for Best Practice. London: Immigration Law Practitioners' Association. 
Irish Refugee Council (2006) Separated Children in Ireland: Losers in a Two-Tier System. Available at http://www.irishrefugeecouncil.ie/press06/separated_children.html, accessed 13 November 2008.

Lane, P. and Tribe, R. (2006) 'Unequal care: an introduction to understanding UK policy and its impact on asylum-seeking children', International Journal of Migration, Health and Social Care, 2(2): $7 ! 14$

Loughry, M. and Eyber, C. (2003) Psychosocial Concepts in Humanitarian Work with Children: A Review of Concepts and Related Literature. Washington DC: National Academies Press.

Refugee Council (2003) Children in Detention: A Refugee Council Policy Paper. London: Refugee Council.

Sen, S. (2000) 'Stateless refugees and the right to return: the Bihari refugees of South Asia', International Journal of Refugee Law, 12(1): $41 ! 70$.

Spicer, N. (2008) 'Places of exclusion and inclusion: asylum-seeker and refugee experiences of neighbourhoods in the UK', Journal of Ethnic and Migration Studies, 34(3): 491!51.

Summerfield, D. (2000) 'Childhood, war, refugeedom and "trauma": three core questions for mental health professionals', Transcultural Psychiatry, 37(3): $417 ! 33$

Thomas, T. and Lau, W. (2002) Psychological Well Being of Child and Adolescent Refugee and Asylum Seekers: Overview of Major Research Findings of the Past Ten Years. Available at: www. humanrights.gov.au/human_rights/children_detention/psy_review.html\#references.

Thomson, S.M. (2007) 'The politics of trauma in post-genocide Rwanda: treatment for some at the expense of the many'. Denver: University of Denver, paper given at the Peacebuilding and Trauma Recovery: Integrated Strategies in Post-War Reconstruction conference, 25 February.

Turton, D. (2002) 'Forced displacement and the nation-state', in Robinson, J. (ed.) Development and Displacement. Oxford: Oxford University Press, $20 ! 75$.

Veale, A. and Dona' , G. (2002) 'Psycho-social interventions and children's rights: beyond clinical interventions', Peace and Conflict: Journal of Peace Psychology, 8(1): $47 ! 61$.

Veale, A. and Dona' , G. (2003) 'Street children and political violence: a socio-demographic analysis of street children in Rwanda', Child Abuse and Neglect: The International Journal, 27(3): 253!69.

Veale, A. and Stavrou, A. (2007) 'Former Lord's Resistance Army child soldier abductees: explorations of identity in reintegration and reconciliation', Peace and Conflict: Journal of Peace Psychology, 13(3): $273 ! 92$.

Veale, A., Quigley, P., Ndibeshye, T. and Nyirimihigo, C. (2001) Struggling to Survive: Orphan and CommunityDependent Children in Rwanda. Kigali: UNICEF.

Wetherell, M., Taylor, S. and Yates, S. (2001) Discourse Theory and Practice: A Reader. London: Sage. 